\title{
MANAGEMENT ACCOUNTING PRACTICES BY SOME SELECTED MANUFACTURING ENTERPRISES ENLISTED IN CHITTAGONG STOCK EXCHANGE, BANGLADESH: AN EVALUATION
}

\section{Md. Musharof Hossain $^{1+}$ \\ Monir Ahmmed ${ }^{2}$ \\ Mohammad \\ Emdad Hossain ${ }^{3}$ \\ Md. Kazi Golam Azam $^{4}$}

\author{
${ }^{1,4}$ Assistant Professor, Department of Business Administration, International \\ Islamic University Chittagong, Bangladesh. \\ ${ }^{2}$ Email: musharof_cu@yahoo.com \\ "Email:mdkgazam@iucuc.ac.bd \\ ${ }^{2}$ Associate Professor, Department of Economics \& Banking, International \\ Islamic University Chittagong, Bangladesh. \\ ${ }^{2}$ Email:monircus7@gmail.com \\ ${ }^{3}$ Associate Professor, Department of Business Administration, International \\ Islamic University Chittagong, Bangladesh. \\ ${ }^{3}$ Email:mehapstat@gmail.com

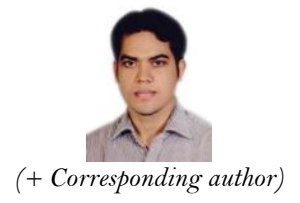 \\ (+ Corresponding author)
}

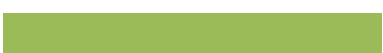

Article History

Received: 3 August 2020 Revised: 8 September 2020 Accepted: 25 September 2020 Published: 14 October 2020

\section{Keywords}

Management accounting Management accounting practices Manufacturing enterprises CSE listed companies Accounting information.

\begin{abstract}
Management accounting (MA) helps to formulate strategies in manufacturing enterprises (ME). This paper is the outcome/product of a study on the Management Accounting Practices (MAP) of Nine (9) manufacturing enterprises from 4 sectors listed in the Chittagong Stock Exchange (CSE) on the year of 2019. The study aims to evaluate the present scenario of MA practices. The primary data were collected through a structured questionnaire from 139 respondents selected from nine enterprises and found that the highest mean score was 4.71, on Management accounting information is very essential for manager to take decision making and lowest mean score is 4.28 , for the practice of management accounting to enhance profitability and the average mean score was 4.4871 in the scale of 5 . The study also revealed that about $59 \%$ to $98 \%$ of enterprises have disclosed the management accounting information both in descriptive $\&$ monetary nature. New and innovative techniques of management accounting should be implemented to gain competitive advantages. The study has recommended improving the management accounting practices in this regard.
\end{abstract}

Contribution/ Originality: This study investigates the scenario of management accounting practices of some manufacturing companies from different sectors listed in CSE based on primary responses from management accountants and found very high score (4.28 to 4.71 out of 5) regarding their intension towards MA practices which may be a significant message for policy-makers.

\section{INTRODUCTION}

Management Accounting (MA) practices is a common phenomenon for manufacturing enterprises in Bangladesh. Manufacturing Enterprises (ME) is used a different technique for the MA process such as budgeting, variance analysis and breakeven analysis. These methods help organizations to plan, direct and control operating costs and to achieve profitability. It is recognized that management accounting practices are important to the success of the organization (Charles, George, \& Chris, 2010). Management accounting is the application of 
appropriate techniques and concepts in processing the historical and projected economic data of an entity to assist management in establishing a plan for reasonable economic objectives and in making rational decisions with a view towards achieving objectives.

Management Accounting helps to create organizational value through better decision making and management of the organization. The development of management accounting is responsive to the demand for management and the environment (McWatter, Morse, \& Zinmmerman, 2001). However, the majority of traditional management accounting practices prevailed during 1970 - 1999 (Shotter, 1999). On the other hand, after the period of 2000 innovative management accounting practices are started of manufacturing organizations for taking strategic decision making. Moreover, some organizations are practicing qualitative information rather than quantitative data. The relationship between MA theory and practices has shown by Cooper, Scapen, and Arnold (1983); Berry (1984); Wilkinsion (1986). Another study, Hoque (1991) has stated the use of particular management accounting techniques.

Management accounting also applies to the organization as economic resources to achieve their goal. MA practices help the organization to keep them alive in the competition of the ever-changing world. The more competition is increasing in the global world the more the importance of management accounting is increasing. It also became essential for the enterprise of Bangladesh too. Management accounting has various tools \& techniques in practice. Every company does not use the same tools \& techniques of MA. Different companies follow different tools for maintaining an account in their organization all over the country. In Bangladesh, a large number of companies follow the traditional system of accounting. In Chittagong very few organizations are used innovative MA techniques like as Just in Time, Transfer pricing, CVP analysis, Cash flow analysis, responsibilities accounting marginal costing, management reporting statistical and operational research techniques. Considering the importance of MA practices and its scanty of research and development activities in the field of accounting literature, the researcher is induced to make a study on the evaluation of MA practices in some ME in Chittagong.

\section{LITERATURE REVIEW}

Considering the importance of MA practices and its scanty of research and development activities in the field of accounting literature, the researcher is induced to make a study on the evaluation of MA practices in some ME in Chittagong.

The status of management accounting practices in the UK industry was evaluated collecting perception from 123 accountants and express that there are four stages in management accounting which is essential in the evaluation in MA. The first stage which was occurs in pre-1950 which was cost determination and financial control. The second stage starts in 1965. This stage can be named by information for management planning and controlling. The third stage was the reduction of resources waste in business processes. The final stage starts in 1995 which related to appropriate resources. The more management accounting approach has used in early 1980 just in time (JIT), total quality management (TQM), Process Reengineering and theory of constraints (Garrison \& Norren, 2003). Management Accounting is also known as the process of identifying, assessing, accumulating, analyzing, organizing, interpreting and communicating information that helps managers fulfill organizational objectives (Hongren, Sundem, \& Stratton, 2002). Three parts of MA are functional, radical \& interpretative. MA will increase the knowledge and understanding of how management accounting information supports manufacturing decision making (Myrelid, 2013). The three manufacturing companies in Barbados who practice MA in their organization. The normal management accounting software is used in companies rather than sophisticated software. Timeliness, effectiveness, information is needed in the organization for practicing management accounting system (Alleyne \& Weekes-Marshall, 2011).

Another study has shown (Gichaaga, 2013) on manufacturing companies in Kenya. Qualitative \& quantitative primary data were collected from 46 manufacturing companies. The study also finds out the management 
accounting function identifies key factors that influence performance and risky areas that require improvements and return on equity (Gichaaga, 2013). Followed, the management accounting techniques used by four Asian countries: Malaysia, Singapore, India \& China. Although updated tools \& techniques like JIT, TQM, ABC, Life Cycle Assessment, and target costing are very significant for enhancing the ability of corporations to meet global competitions, these four countries like to follow traditional tools \&techniques (Sulaiman \& Bhatti, 2013). Furthermore, In Bangladesh there was no statutory enactment is maintained in Bangladesh till 1994 in manufacturing companies (Sharkar, Sobhan, \& Sultana, 2006). Only two specific sections are provided in the Companies Act,1994. Managerial accounting is taken accountable for properly use the recourses for strategic cost management (Weygandt, Kimmel, \& Kieso, 2008). The status of using management accounting practices in a manufacturing firm in Bangladesh (Biswas, Akterujjaman, \& Yasmin, 2014). However, the author stated that the relationship between accounting and organizational decision making has been an influential basis for the analysis, development, and articulation of normative accounting roles and solutions (Burchell \& Nahapiet, 1980). The impact of advanced Management practice in Malaysia. Another study about MAP in Greece 2015 stated that the before and after the Economic crisis of MAP in Greece. However, the effect of ERP software \& advanced MAP in Turkey (Eker \& Aytac, 2016) MAP used in large \& Medium and small total of 160 Czech Companies (Ladislav, 2016). In the Malaysian context, Al Amosh and Mansor (2018) the most of the manufacturing SMEs organization are still used in traditional MAPs while the factors affecting MAP in Malaysia. It is noted that, A sample of Pakistani companies from various sectors in MAP (Shahzadi, Khan, Toor, \& ul Haq, 2018). On the other hand, the MAP of 161 manufacturing companies in Vietnam (Hieu \& Dung, 2018). Another study has shown (Gichaaga, 2013) on manufacturing companies in Kenya. Qualitative \& quantitative primary data were collected from 46 manufacturing companies. The study also finds out the management accounting function identifies key factors that influence performance and risky areas that require improvements and return on equity (Gichaaga, 2013). Followed, the management accounting techniques used by four Asian countries: Malaysia, Singapore, India \& On the basis of the overall literature review, most of the authors have shown very poor information on management accounting practices in a manufacturing organization. But management accounting practice is still in an infant stage in the developing country like Bangladesh. Basically, in the Chittagong based manufacturing organizations are very few practices in management accounting. So, the researcher has got the interest to make a study on MA practices in ME of Bangladesh.

\section{OBJECTIVES OF THE STUDY}

- To evaluate the management accounting practices in manufacturing enterprises listed in Chittagong Stock Exchange.

- To give the policy recommendations towards management accounting practices of manufacturing enterprises in Chittagong Stock Exchange.

\section{METHODOLOGY OF THE STUDY}

This part describes sample selection, selection of period, selection of respondents, source of data, and analysis of data.

\subsection{Sample Selection}

For conducting this study an afford is given for the collection of data from nine (9) purposively selected manufacturing organizations. In this study, all companies are situated in Chittagong. The researcher has taken the current data of all sample enterprises. Two (2) companies are from the cement sector, three (3) companies from the food sector, Three (3) from the textile industry and one (1) from the Pharmaceutical sector. 
Table-1. Samples of the enterprises

\begin{tabular}{ll|ll}
\hline Sector & \multicolumn{2}{l}{ Company Name } \\
\hline 1. & Textile & 1. & Clifton Textiles and Apparels Ltd \\
& 2. & Univogue Garments Company Ltd. \\
& 3. & Tex Designs Garments Manufacturer \& exporter. \\
\hline 2. & Cement & 4. & Premier Cement Mill Limited. \\
& 5. & Confidence Cement Limited. \\
\hline 3. Foods & 1. & AbulKhair Group. \\
& 2. & Good Food \& Confectionaries. \\
& 3. & Karnofuli food Private limited. \\
\hline 4. & Pharmaceutical & 1. & Glaxo SmithKline Bangladesh Limited. \\
\hline \multicolumn{2}{l}{ Total 4 sector } & \multicolumn{2}{c}{ Total 9 Companies. } \\
\hline
\end{tabular}

\subsection{Selection of Respondents}

The researcher has collected perceptions from the respondent of the selected company. The targeted one hundred eighty (180) respondents from nine (9) companies' e.i., $9^{*} 20=180$. The researcher has collected a minimum of 19 respondents from each company. But, it collected a total of 139 respondents from all selected companies. Respondents feel nervous about whether their financial position may disclose in the questionnaire. So the researcher fails to collect target perception from the survey. The researcher has collected twenty-eight (28) respondents from cement sectors, forty-six (46) respondents from food industry, forty-six (46) respondents from the textile industry and nineteen (19) respondents from Pharmaceuticals industry.

\subsection{Data Sources}

Data was collected from targeted field. Total 139 respondents have given on the basis of the questionnaire. Total data sources have shown in table:

Table-2. Targeted respondents

\begin{tabular}{l|l|c|c|c}
\hline Sector & Companies & Respondents & \% of company & \% of Sectors \\
\hline \multirow{2}{*}{ Textile } & Clifton Textiles and Apparales Ltd. & 14 & $10.25 \%$ & \multirow{2}{*}{$33.33 \%$} \\
\cline { 2 - 4 } & Univogue Garments Company Ltd. & 18 & $12.83 \%$ & \\
\cline { 2 - 4 } & $\begin{array}{l}\text { Tex Designs Garments Manufacturer \& } \\
\text { exporter }\end{array}$ & 14 & $10.25 \%$ & \\
\hline \multirow{2}{*}{ Fement } & Premier Cement Mill Limited & 14 & $10.25 \%$ & \multirow{2}{*}{$20.5 \%$} \\
\cline { 2 - 4 } & Confidence Cement Limited & 14 & $10.25 \%$ & \multirow{2}{*}{$33.33 \%$} \\
\cline { 2 - 4 } & 1.Abul Khair Group & 18 & $12.83 \%$ & $12.84 \%$ \\
\cline { 2 - 4 } & 2.Good Food \& Confectionaries & 14 & $10.25 \%$ & $100 \%$ \\
\hline & 3.Karnofuli food Private limited & 19 & $12.84 \%$ & \\
\hline
\end{tabular}

\subsection{Data Collection}

Purposive and non-probabilistic sampling techniques have been used for this study. A structured questionnaire both (dichotomous and 5 points Likert scale) has been used for the collection of data. The primary data have been gathered through questionnaires from the AGM, Manager, MD, accountants of various departments of a selected manufacturing organization. To measure the perception in 5 points Likert scale, descriptive statistics have been used in the analysis part.

\subsection{Data Reliability}

Reliability of data has been tested by famous method Cron Bach's Alpha and the result was follows: 
Table-3. Reliability test.

\begin{tabular}{c|c}
\hline CronBach's Alpha & N of items \\
\hline .878 & 10 \\
\hline
\end{tabular}

The above table shows that value 0.878 mean that the reliability of the data is $87.8 \%$ which is quite acceptable as per decision rule.

\section{RESULT \& DISCUSSION}

In this part analysis of data has been made. The questionnaire has been prepared to collect information from 139 respondents of selected 9 manufacturing enterprises of Chittagong Stock Exchange.

\subsection{Management Accounting Practice Based on Organization Perceptions}

Table-4. MAP of sample enterprises.

Do you have separate management accounting department?

\begin{tabular}{c|c|c|c|c|c}
\hline \multicolumn{2}{c|}{} & Frequency & Percent & Valid Percent & $\begin{array}{c}\text { Cumulative } \\
\text { Percent }\end{array}$ \\
\hline \multirow{3}{*}{ Valid } & No & 43 & 30.8 & 30.8 & 30.8 \\
\cline { 2 - 6 } & yes & 96 & 69.2 & 69.2 & 100.0 \\
\cline { 2 - 6 } & Total & 139 & 100.0 & 100.0 & \\
\hline
\end{tabular}

Do you think the organization is benefiting from the management accounting function?

\begin{tabular}{c|c|c|c|c|c}
\hline \multicolumn{2}{c|}{} & Frequency & Percent & Valid Percent & $\begin{array}{c}\text { Cumulative } \\
\text { Percent }\end{array}$ \\
\hline \multirow{3}{*}{ Valid } & No & 32 & 23.1 & 23.1 & 23.1 \\
\cline { 2 - 6 } & Yes & 107 & 76.9 & 76.9 & 100.0 \\
\cline { 2 - 6 } & Total & 139 & 100.0 & 100.0 & \\
\hline
\end{tabular}

Do you think management accounting assists management in formulating the strategy of planning and control?

\begin{tabular}{c|c|c|c|c|c}
\hline \multicolumn{2}{c|}{} & Frequency & Percent & Valid Percent & $\begin{array}{c}\text { Cumulative } \\
\text { Percent }\end{array}$ \\
\hline \multirow{3}{*}{ Valid } & No & 28 & 20.5 & 20.5 & 20.5 \\
\cline { 2 - 6 } & Yes & 111 & 79.5 & 79.5 & 100.0 \\
\cline { 2 - 6 } & Total & 139 & 100.0 & 100.0 & \\
\hline
\end{tabular}

Does management accounting provide competitive advantage for an organization?

\begin{tabular}{c|c|c|c|c|c}
\hline \multicolumn{2}{c|}{} & Frequency & Percent & Valid Percent & $\begin{array}{c}\text { Cumulative } \\
\text { Percent }\end{array}$ \\
\hline \multirow{3}{*}{ Valid } & No & 11 & 7.7 & 7.7 & 7.7 \\
\cline { 2 - 6 } & yes & 128 & 92.3 & 92.3 & 100.0 \\
\cline { 2 - 6 } & Total & 139 & 100.0 & 100.0 & \\
\hline
\end{tabular}

Does the company follow quality of conformance?

\begin{tabular}{c|c|c|c|c|c}
\hline \multicolumn{2}{c|}{} & Frequency & Percent & Valid Percent & $\begin{array}{c}\text { Cumulative } \\
\text { Percent }\end{array}$ \\
\hline \multirow{3}{*}{ Valid } & No & 50 & 35.9 & 35.9 & 35.9 \\
\cline { 2 - 6 } & yes & 89 & 64.1 & 64.1 & 100.0 \\
\cline { 2 - 6 } & Total & 139 & 100.0 & 100.0 & \\
\hline
\end{tabular}


Does the company maintain ISO -9000 standard?

\begin{tabular}{c|c|c|c|c|c}
\hline \multicolumn{2}{c|}{} & Frequency & Percent & Valid Percent & $\begin{array}{c}\text { Cumulative } \\
\text { Percent }\end{array}$ \\
\hline \multirow{3}{*}{ Valid } & No & 57 & 41.0 & 41.0 & 41.0 \\
\cline { 2 - 6 } & yes & 82 & 59.0 & 59.0 & 100.0 \\
\cline { 2 - 6 } & Total & 139 & 100.0 & 100.0 & \\
\hline
\end{tabular}

Does company use CVP analysis for taking decision?

\begin{tabular}{c|c|c|c|c|c}
\hline \multicolumn{2}{c|}{} & Frequency & Percent & Valid Percent & $\begin{array}{c}\text { Cumulative } \\
\text { Percent }\end{array}$ \\
\hline \multirow{3}{*}{ Valid } & No & 7 & 5.1 & 5.1 & 5.1 \\
\cline { 2 - 6 } & yes & 132 & 94.9 & 94.9 & 100.0 \\
\cline { 2 - 6 } & Total & 139 & 100.0 & 100.0 & \\
\hline
\end{tabular}

Does ABC help to maintain strategic costing system?

\begin{tabular}{c|c|c|c|c|c}
\hline \multicolumn{2}{c|}{} & Frequency & Percent & Valid Percent & $\begin{array}{c}\text { Cumulative } \\
\text { Percent }\end{array}$ \\
\hline \multirow{3}{*}{ Valid } & No & 7 & 5.1 & 5.1 & 5.1 \\
\cline { 2 - 6 } & yes & 132 & 94.9 & 94.9 & 100.0 \\
\cline { 2 - 6 } & Total & 139 & 100.0 & 100.0 & \\
\hline
\end{tabular}

Does pricing ( used by management accounting Techniques ) help to take decision for achieving the objectives of the organization

\begin{tabular}{c|c|c|c|c|c}
\hline \multicolumn{2}{c|}{} & Frequency & Percent & Valid Percent & $\begin{array}{c}\text { Cumulative } \\
\text { Percent }\end{array}$ \\
\hline \multirow{3}{*}{ Valid } & No & 4 & 2.6 & 2.6 & 2.6 \\
\cline { 2 - 6 } & yes & 135 & 97.4 & 97.4 & 100.0 \\
\cline { 2 - 6 } & Total & 139 & 100.0 & 100.0 & \\
\hline
\end{tabular}

Do you receive the management accounting reports on performance relative to establish objectives?

\begin{tabular}{c|c|c|c|c|c}
\hline \multicolumn{2}{c|}{} & Frequency & Percent & Valid Percent & $\begin{array}{c}\text { Cumulative } \\
\text { Percent }\end{array}$ \\
\hline \multirow{3}{*}{ Valid } & No & 32 & 23.1 & 23.1 & 23.1 \\
\cline { 2 - 6 } & yes & 107 & 76.9 & 76.9 & 100.0 \\
\cline { 2 - 6 } & Total & 139 & 100.0 & 100.0 & \\
\hline
\end{tabular}

Is the information provided in sufficient detail and on time to enable carring out decision making efficiently?

\begin{tabular}{c|c|c|c|c|c}
\hline \multicolumn{2}{c|}{} & Frequency & Percent & Valid Percent & $\begin{array}{c}\text { Cumulative } \\
\text { Percent }\end{array}$ \\
\hline \multirow{3}{*}{ Valid } & No & 18 & 12.8 & 12.8 & 12.8 \\
\cline { 2 - 6 } & yes & 121 & 87.2 & 87.2 & 100.0 \\
\cline { 2 - 6 } & Total & 139 & 100.0 & 100.0 & \\
\hline
\end{tabular}

Does your organization take information which is collect from management accounting techniques as a strategic decision?

\begin{tabular}{c|c|c|c|c|c}
\hline \multicolumn{2}{c|}{} & Frequency & Percent & Valid Percent & $\begin{array}{c}\text { Cumulative } \\
\text { Percent }\end{array}$ \\
\hline \multirow{3}{*}{ Valid } & No & 14 & 10.3 & 10.3 & 10.3 \\
\cline { 2 - 6 } & yes & 125 & 89.7 & 89.7 & 100.0 \\
\cline { 2 - 6 } & Total & 139 & 100.0 & 100.0 & \\
\hline
\end{tabular}


Does management accounting department is essential for manufacturing organization?

\begin{tabular}{c|c|c|c|c|c}
\hline \multicolumn{2}{c|}{} & Frequency & Percent & Valid Percent & $\begin{array}{c}\text { Cumulative } \\
\text { Percent }\end{array}$ \\
\hline \multirow{3}{*}{ Valid } & No & 4 & 2.6 & 2.6 & 2.6 \\
\cline { 2 - 6 } & yes & 135 & 97.4 & 97.4 & 100.0 \\
\cline { 2 - 6 } & Total & 139 & 100.0 & 100.0 & \\
\hline
\end{tabular}

Note: Frequency distribution relevant to MA practices of the sample enterprises.

Above discussion shows the frequency distribution based on organizational perceptions. It is noted that, the highest $97.4 \%$ positive answer has given on the statement (13 \& 9) "Does pricing (used by management accounting techniques) help to take decision for achieving the objectives of the organization" \& "Does management accounting department is essential for manufacturing organization?”, and the second highest $94.87 \%$ on the statement (8) "Does ABC helps to maintain strategic costing system?". Finally, the lowest $58.97 \%$ response has given on the statement "Does the company maintain ISO -9000 standard?"

\subsection{Outcome of Management Accounting Practices based on Respondents Perception}

Table-5. Respondents Perception.

\begin{tabular}{|c|c|c|c|c|}
\hline & \multicolumn{4}{|c|}{ Descriptive Statistics } \\
\hline No & & $\mathbf{N}$ & Mean & Std. Deviation \\
\hline 1 & $\begin{array}{l}\text { A management accountant of manufacturing } \\
\text { organization analyse the cost behavior for cost } \\
\text { prediction. }\end{array}$ & 139 & 4.5897 & .67738 \\
\hline 2 & $\begin{array}{l}\text { CVP analysis helps in management acc. to } \\
\text { understand the inter-relation among cost, volume } \\
\text { and profits of manufacturing organization. }\end{array}$ & 139 & 4.3590 & .48597 \\
\hline 3 & $\begin{array}{l}\text { Absorption costing and variable costing are used for } \\
\text { managerial decision making in manufacturing } \\
\text { organization. }\end{array}$ & 139 & 4.4359 & .75376 \\
\hline 4 & $\begin{array}{l}\text { The management accounting assists in activity based } \\
\text { costing }(A B C) \text { in manufacturing organization. }\end{array}$ & 139 & 4.2821 & .68628 \\
\hline 5 & $\begin{array}{l}\text { The Management accounting helps in comparing the } \\
\text { actual and planned outcome of manufacturing } \\
\text { organization. }\end{array}$ & 139 & 4.3333 & .70088 \\
\hline 6 & $\begin{array}{l}\text { Management accounting is generates information for } \\
\text { making capital budgeting decisions. }\end{array}$ & 139 & 4.7179 & .51035 \\
\hline 7 & $\begin{array}{l}\text { Management accounting is used for formulating the } \\
\text { strategic planning of the manufacturing } \\
\text { organization. }\end{array}$ & 139 & 4.3590 & .62774 \\
\hline 8 & $\begin{array}{l}\text { Management accounting information is very } \\
\text { essential for management to take decision-making. }\end{array}$ & 139 & 4.7179 & .51035 \\
\hline 9 & $\begin{array}{l}\text { The practice of management accounting has } \\
\text { enhanced by Profitability. }\end{array}$ & 139 & 4.2821 & .68628 \\
\hline 10 & Pricing product is essential for MA practices. & 139 & 4.4103 & .71517 \\
\hline & Average mean score & & 4.4871 & \\
\hline & Valid N (listwise) & 139 & & \\
\hline
\end{tabular}

This part of the study shows the outcome of the MA techniques based on the perception of respondents. The 5 point scale measurement is applied to the collection of data. From the above table, the highest mean score is a statement no $6 \& 8$ in statement 6 is "management accounting generates information for making capital budgeting decisions" and 8 is "Management accounting information is very essential for a manager to take decision making" both mean score is 4.7179 . The lowest mean score is 4.3333 for the statements "The management accounting helps in comparing the actual and planned outcome of manufacturing organization". 
Table-6. Ranking of the Statements

\begin{tabular}{l|l|c}
\hline Rank & Statements & Percent \\
\hline 1 & $\begin{array}{l}\text { Management accounting information is very essential for management to take } \\
\text { decision-making. }\end{array}$ & $74.4 \%$ \\
\hline 1 & $\begin{array}{l}\text { Management accounting in generates information for making capital budgeting } \\
\text { decision }\end{array}$ & $74.4 \%$ \\
\hline 2 & $\begin{array}{l}\text { A management accountant of manufacturing industry analyzes the cost behavior for } \\
\text { cost prediction. }\end{array}$ & $66.7 \%$ \\
\hline 3 & $\begin{array}{l}\text { CVP analysis helps in management accounting to understand the inter-relation } \\
\text { among cost, volume and profits of manufacturing organization. }\end{array}$ & $64.1 \%$ \\
\hline 4 & $\begin{array}{l}\text { The management accounting assists in activity-based costing (ABC) in } \\
\text { manufacturing organization. }\end{array}$ & $59.0 \%$ \\
\hline 4 & $\begin{array}{l}\text { The practice of management accounting has enhanced by Profitability. } \\
\text { manufacturing industry. }\end{array}$ & $59.0 \%$ \\
\hline 5 & $\begin{array}{l}\text { Management accounting is used for formulating the strategic planning of the } \\
\text { manufacturing industry. }\end{array}$ & $56.4 \%$ \\
\hline 5 & $\begin{array}{l}\text { The management accounting helps in comparing the actual and planned outcome of } \\
\text { manufacturing organization. }\end{array}$ & $53.8 \%$ \\
\hline 6 & Pricing product is essential for MA practices. & $53.8 \%$ \\
\hline
\end{tabular}

Based on the Table 6, the researcher got the highest perception shown the two statements of "Management accounting information is very essential for management to take decision-making 74.4\%" \& "management accounting generates information for making capital budget decision $74.4 \%$ ” and the lowest percentage have shown also two statements $53.8 \%$ are the "management accounting helps in comparing the actual and planned outcome of manufacturing organization". \& "Pricing product is essential for MA practices".

5.4. Findings

The study is concerned with Management accounting practices of some selected manufacturing enterprises listed in CSE in Bangladesh. To reveal the purpose of the study the researcher has considered the 139 respondents (stakeholders) from nine enterprises of four sectors and revealed about 59\% to $98 \%$ of enterprises disclose the management accounting information both in descriptive \& monetary nature. To get the status of Management accounting practices by the enterprises we have raised (10) indicative questions to the respondents selected from the relevant enterprises and got that the highest mean score was 4.71 on Management accounting information is very essential for manager to take decision making and lowest mean score is 4.28 for the practice of management accounting has enhanced by Profitability and the average mean score was 4.4871 in the scale of 5 . The majority of respondents have given perceptions on CVP analysis is used by their company which is very fruitful. Moreover, $74.4 \%$ (103) respondents have given perception management accounting help to generate information for making capital budgeting decisions. As regard, $69 \%$ of respondents said they have shown a separate management accounting department in the organization.

Although, there are no Generally Accepted Management Accounting principles for the manufacturing enterprises. Rules and regulations for management accounting practices in the right way were yet established \& Government initiatives were not still enough to build a strong platform of the Manufacturing Industry.

\section{RECOMMENDATIONS \& CONCLUSION}

Management accounting is very essential for a manufacturing organization. Although, it is very significant to practice new and innovative management accounting techniques to get a competitive advantage also for strategic 
planning for their organization. From our study, it is found that $41 \%$ of respondents do believe that enterprises are not following ISO-900 standards and also revealed that $47 \%$ of respondents do believe that enterprises are not following standard costing \& pricing product policy. Moreover, manufacturing organizations should focus on the absorption costing perspective and also capital budgeting. Manufacturing companies should be given training and knowledge on management accounting software as nowadays accounting practices are based on a software basis.

The study revealed that management accounting performs a crucial role in manufacturing organizations in the Chittagong Stock Exchange. In the context of Chittagong, a manufacturing organization is recently applying management accounting techniques to take a strategic decision, perform managerial activities and control over cost.

Funding: This study received no specific financial support.

Competing Interests: The authors declare that they have no competing interests.

Acknowledgement: All authors contributed equally to the conception and design of the study.

\section{REFERENCES}

Al Amosh, H. A. M., \& Mansor, N. (2018). Sustainability and corporate reporting: A review on environmental and social accounting disclosure. International Journal of Accounting, 3(8), 78-87.

Alleyne, P., \& Weekes-Marshall, D. (2011). An exploratory study of management accounting practices in manufacturing companies in Barbados. International Journal of Business and Social Science, 2(9), 49-58.

Berry, A. J. (1984). The control of capital investment. Journal of Management Studies, 21(1), 61-81.

Biswas, M., Akterujjaman, S., \& Yasmin, A. (2014). Management accounting practices in the manufacturing business firms in Bangladesh. BUFT Journal, 2, 87-97.

Burchell, S., \& Nahapiet, J. (1980). The roles of accounting in organizations and society. Accounting, Organizations and Society, $5(1), 5-21$.

Charles, T. H., George, F., \& Chris, I. (2010). Cost accounting: A managerial emphasis. Issues in Accounting Education, 25(4), 789790. Available at: https://doi.org/10.2308/iace.2010.25.4.789.

Cooper, D., Scapen, R. W., \& Arnold, J. (1983). Management accounting research and practice. London: CIMA.

Eker, M., \& Aytac, A. (2016). Effects of interaction between ERP and advanced management accounting techniques on firm performance evidence from Turkey. Journal of Accounting \& Finance, 7(2), 187-209.

Garrison, R. H., \& Norren, E. W. (2003). Management accounting (10th ed.). Federick, MD,USA: Mcgraw-Hill(Tx) Publisher, WonderBook.

Gichaaga, P. M. (2013). Effects of management accounting practices on financial performance of manufacturing companies in Kenya. Rechearch Report for Masters, University of Nairobi.

Hieu, P., \& Dung, B. (2018). Management accounting practices in Vietnam: An empirical study. Account and Financial Management Journal, 3(7), 1616-1620. Available at: https://doi.org/10.31142/afmj/v3i7.02.

Hongren, C. T., Sundem, G. L., \& Stratton, W. O. (2002). Introduction to management accounting. New Delhi: Pearson Education (Singapore) Pte Ltd.

Hoque, Z. (1991). Researching management accounting practice: The debate about quantitative and qualitative research. Dha $a$ University Journal of Business Studies, 12(2), 19-32.

Ladislav, S. (2016). The contingency factors affecting management accounting in Czech companies. Applications of Agriculture and Silviculturae Mendelianae Brno, 64(4), 1383-1392. Available at: https://doi.org/10.11118/actaun201664041383.

McWatter, C. S., Morse, D. C., \& Zinmmerman, J. L. (2001). Management accounting analysis and interpretation. New York, NY: McGraw- Hill/Irwin.

Myrelid, A. (2013). Essays on manufacturing-related management accounting. Doctoral Dissertation, Linköping University Electronic Press.

Shahzadi, S., Khan, R., Toor, M., \& ul Haq, A. (2018). Impact of external and internal factors on management accounting practices: A study of Pakistan. Asian Journal of Accounting Research, 3(2), 21 1-223. 
Sharkar, M. Z. H., Sobhan, M., \& Sultana, S. (2006). Management accounting development and practices in Bangladesh. Brac University Journal, 3(2), 113-124.

Shotter, M. (1999). The origin and development of management accounting. Meditari Accountancy Research, 1(23), $209-235$.

Sulaiman, M., \& Bhatti, O. K. (2013). Workplace deviance and spirituality in Muslim organizations. Asian Social Science, 9(10), $237-246$.

Weygandt, J. J., Kimmel, P. D., \& Kieso, D. E. (2008). Managerial accounting tools for business decision making. USA: John Wiley \& Sons.

Wilkinsion, C. (1986). Towardsa theory of management control system: A case study approach. Unpublished Ph.D Thesis. U.K. University of Lancaster.

Appendix 1: Confidential

Questionnaire

General Information:

Name of Respondent:

Education Qualification:

Designation:

Name of Organization

Type of organization: (Textile/ Cement/ Food/ Leather/ Paper/ Parma/ Ceramic/ Energy/ Miscellaneous)

Year of organization Establishment:

Cost of Quality report: $\square$ Yes $\square$ No

Specific Information

Part One (Management Accounting practices of manufacturing organization)

1) Do you have separate Management accounting department/section?

$\square$ Yes $\square \mathrm{No}_{0}$

2) Do you think the organization is benefiting from the Management accounting function?

$\square$ Yes $\square \mathrm{No}_{0}$

3) Do you think management accounting assists management in formulating policies and in planning and control of operation of the undertaking?

$\square$ Yes $\square$ No

4) Does management accounting provide competitive advantage for an organization?

$\square$ Yes $\square$ No

5) Does the company follow quality of conformance?

$\square$ Yes $\square$ No

6) Does the company maintain ISO -9000 standard?

$\square$ Yes $\square$ No

7) Does company use CVP analysis for taking decision?

$\square$ Yes $\square$ No

8) ABC helps to maintain strategic costing system?

$\square$ Yes $\square$ No

9) Does pricing (used by management accounting Techniques) help to take decision for achieving of the organization?

$\square$ Yes $\square$ No

10) Do you receive the management accounting reports on performance relative to establish objectives?

Yes $\square$ No 
11) Is the information provided in sufficient detail and on time to enable carrying out decision making efficiently?

Yes $\square$ No

12) Does your organization take information which is collect from management accounting techniques as strategic assets?

$\square$ Yes $\square$ No

13) Do you think management accounting department is essential for manufacturing organization?

$\square$ Yes $\square$ No

Part Two (Respondent perception of management accounting practices)

Here is given the following scale with five responses (Strongly Agree=5, Agree=4, Neutral=3, Disagree=2, strongly disagree=1) Put a tick mark in the following level of agreement

Appendix-1. Respondent perception.

\begin{tabular}{|c|c|c|c|c|c|}
\hline Statements & 5 & 4 & 3 & 2 & 1 \\
\hline \multicolumn{6}{|l|}{$\begin{array}{l}\text { A management accountant of manufacturing industry analyse the cost behaviour for cost } \\
\text { prediction. }\end{array}$} \\
\hline \multicolumn{6}{|l|}{$\begin{array}{l}\text { CVP analysis helps in management acc.to understand the inter-relation among cost, } \\
\text { volumn and profits of manufacturing industry. }\end{array}$} \\
\hline \multicolumn{6}{|l|}{$\begin{array}{l}\text { Absorption costing and variable costing are used for managerial decision making in } \\
\text { manufacturing industry }\end{array}$} \\
\hline \multicolumn{6}{|l|}{$\begin{array}{l}\text { The management accounting assists in activity based costing (ABC) in manufacturing } \\
\text { industry }\end{array}$} \\
\hline \multicolumn{6}{|l|}{$\begin{array}{l}\text { The Management accounting helps in comparing the actual and planned outcome of } \\
\text { manufacturing organization. }\end{array}$} \\
\hline \multicolumn{6}{|l|}{ Management accounting is generates information for making capital budgeting decisions. } \\
\hline \multicolumn{6}{|l|}{$\begin{array}{l}\text { Management accounting is used for formulating the strategic planning of the } \\
\text { manufacturing industry }\end{array}$} \\
\hline \multicolumn{6}{|l|}{$\begin{array}{l}\text { Management accounting provides information from its environment to management to } \\
\text { facilitate decision-making }\end{array}$} \\
\hline \multicolumn{6}{|l|}{ Profitability has increased as a result of application of management accounting practices } \\
\hline Pricing products is very essential for MA practices. & & & & & \\
\hline
\end{tabular}

Source: Based on Literature Review.

Appendix-2. Frequency table based on respondents perception.

A management accountant of manufacturing industry analyse the cost behaviour for cost prediction.

\begin{tabular}{|c|c|c|c|c|c|}
\hline & & Frequency & Percent & Valid Percent & Cumulative Percent \\
\hline \multirow{5}{*}{ Valid } & Disagree & 4 & 2.6 & 2.6 & 2.6 \\
\hline & Neutral & 4 & 2.6 & 2.6 & 5.1 \\
\hline & Agree & 39 & 28.2 & 28.2 & 33.3 \\
\hline & Strongly Agree & 92 & 66.7 & 66.7 & 100.0 \\
\hline & Total & 139 & 100.0 & 100.0 & \\
\hline
\end{tabular}

CVP analysis helps in management acc.to understand the inter-relation among cost, volumn and profits of manufacturing industry.

\begin{tabular}{c|c|c|c|c|c}
\hline \multicolumn{2}{c|}{} & Frequency & Percent & Valid Percent & Cumulative Percent \\
\hline \multirow{3}{*}{ Valid } & Agree & 89 & 64.1 & 64.1 & 64.1 \\
\cline { 2 - 6 } & Strongly Agree & 50 & 35.9 & 35.9 & 100.0 \\
\cline { 2 - 6 } & Total & 139 & 100.0 & 100.0 & \\
\hline
\end{tabular}


Absorption costing and variable costing are used for managerial decision making in manufacturing industry

\begin{tabular}{c|c|c|c|c|c}
\hline \multicolumn{2}{|c|}{} & Frequency & Percent & Valid Percent & Cumulative Percent \\
\hline \multirow{4}{*}{ Valid } & Disagree & 4 & 2.6 & 2.6 & 2.6 \\
\cline { 2 - 6 } & Neutral & 11 & 7.7 & 7.7 & 10.3 \\
\cline { 2 - 6 } & Agree & 46 & 33.3 & 33.3 & 43.6 \\
\cline { 2 - 6 } & Strongly Agree & 78 & 56.4 & 56.4 & 100.0 \\
\cline { 2 - 6 } & Total & 139 & 100.0 & 100.0 & \\
\hline
\end{tabular}

The management accounting assists in activity based costing $(\mathrm{ABC})$ in manufacturing industry

\begin{tabular}{|c|c|c|c|c|c|}
\hline & & Frequency & Percent & Valid Percent & Cumulative Percent \\
\hline \multirow{4}{*}{ Valid } & Neutral & 18 & 12.8 & 12.8 & 12.8 \\
\hline & Agree & 64 & 46.2 & 46.2 & 59.0 \\
\hline & Strongly Agree & 57 & 41.0 & 41.0 & 100.0 \\
\hline & Total & 139 & 100.0 & 100.0 & \\
\hline
\end{tabular}

The Management accounting helps in comparing the actual and planned outcome of manufacturing organization.

\begin{tabular}{c|c|c|c|c|c}
\hline \multicolumn{1}{c|}{} & Frequency & Percent & Valid Percent & Cumulative Percent \\
\hline \multirow{4}{*}{ Valid } & Neutral & 18 & 12.8 & 12.8 & 12.8 \\
\cline { 2 - 6 } & Agree & 57 & 41.0 & 41.0 & 53.8 \\
\cline { 2 - 6 } & Strongly Agree & 64 & 46.2 & 46.2 & 100.0 \\
\cline { 2 - 6 } & Total & 139 & 100.0 & 100.0 & \\
\hline
\end{tabular}

Management accounting in generates information for making capital budgeting decisions

\begin{tabular}{c|c|c|c|c|c}
\hline \multicolumn{5}{c}{} & \multicolumn{4}{c}{ Frequency } & Percent & Valid Percent & Cumulative Percent \\
\hline \multirow{4}{*}{ Valid } & Neutral & 4 & 2.6 & 2.6 & 2.6 \\
\cline { 2 - 6 } & Agree & 32 & 23.1 & 23.1 & 25.6 \\
\cline { 2 - 6 } & Strongly Agree & 103 & 74.4 & 74.4 & 100.0 \\
\cline { 2 - 6 } & Total & 139 & 100.0 & 100.0 & \\
\hline
\end{tabular}

Management accounting is used for formulating the strategic planning of the manufacturing industry

\begin{tabular}{|c|c|c|c|c|c|}
\hline & & Frequency & Percent & Valid Percent & Cumulative Percent \\
\hline \multirow{4}{*}{ Valid } & Disagree & 4 & 2.6 & 2.6 & 2.6 \\
\hline & Agree & 78 & 56.4 & 56.4 & 59.0 \\
\hline & Strongly Agree & 57 & 41.0 & 41.0 & 100.0 \\
\hline & Total & 39 & 100.0 & 100.0 & \\
\hline
\end{tabular}

Management accounting information is very essential for management to take decision-making.

\begin{tabular}{|c|c|c|c|c|c|}
\hline & & Frequency & Percent & Valid Percent & Cumulative Percent \\
\hline \multirow{4}{*}{ Valid } & Neutral & 4 & 2.6 & 2.6 & 2.6 \\
\hline & Agree & 32 & 23.1 & 23.1 & 25.6 \\
\hline & Strongly Agree & 103 & 74.4 & 74.4 & 100.0 \\
\hline & Total & 139 & 100.0 & 100.0 & \\
\hline
\end{tabular}

The practice of management accounting has enhanced by Profitability.

\begin{tabular}{c|c|c|c|c|c}
\hline \multicolumn{2}{c|}{} & Frequency & Percent & Valid Percent & Cumulative Percent \\
\hline \multirow{4}{*}{ Valid } & Neutral & 18 & 12.8 & 12.8 & 12.8 \\
\cline { 2 - 6 } & Agree & 64 & 46.2 & 46.2 & 59.0 \\
\cline { 2 - 6 } & Strongly Agree & 57 & 41.0 & 41.0 & 100.0 \\
\cline { 2 - 6 } & Total & 139 & 100.0 & 100.0 & \\
\hline
\end{tabular}


Journal of Asian Business Strategy, 2020, 10(1): 159-171

Pricing product is essential for MA practices

\begin{tabular}{c|c|c|c|c|c}
\hline \multicolumn{2}{c|}{} & Frequency & Percent & Valid Percent & Cumulative Percent \\
\hline \multirow{4}{*}{ Valid } & Neutral & 18 & 12.8 & 12.8 & 12.8 \\
\cline { 2 - 6 } & Agree & 46 & 33.3 & 33.3 & 46.2 \\
\cline { 2 - 6 } & Strongly Agree & 75 & 53.8 & 53.8 & 100.0 \\
\cline { 2 - 6 } & Total & 139 & 100.0 & 100.0 & \\
\hline
\end{tabular}

Views and opinions expressed in this article are the views and opinions of the author(s), Journal of Asian Business Strategy shall not be responsible or answerable for any loss, damage or liability etc. caused in relation to/arising out of the use of the content. 